\title{
The Effectiveness of Implementing Noble Values through Online Problem-Based Learning Among Students in Higher Learning Institution
}

\author{
$1^{\text {st }}$ Gamal Abdul Nasir Zakaria ${ }^{1}, 2^{\text {nd }}$ Aliff Nawi ${ }^{2}$ \\ \{gamal.zakaria@ubd.edu.bn ${ }^{1}$, aliffnawi@uum.edu. ${ }^{2}$ \}
}

\begin{abstract}
Sultan Hassanal Bolkiah Institute of Education, Universiti Brunei Darussalam, Brunei ${ }^{1}$, School of
\end{abstract} Education, Universiti Utara Malaysia, Malaysia²

\begin{abstract}
Implementing noble values is the process of applying noble values until it can develop or promote good attitude and behavior. Implementing noble values can be applied in various ways such as in speech, behavior, gesturing, comprehension, assessment, exemplary and content in accordance with the subject and creativity of the teacher. This study aims to see the effectiveness of applying noble values through problem-based learning. A total of 81 students were involved in the study and they were divided into treatment and control groups. In order to identify the effectiveness of the module in applying values, the quasi-experimental method was used through questionnaires. The results showed that there was a significant effect on the application of value in the treatment group. The findings also revealed that learning through PBL can provide a different learning environment as compared to regular learning sessions. The implication of this study can directly provide an alternative in applying values to the students themselves.
\end{abstract}

Keywords: Noble Values, PBL, Module, Islamic Education, Higher institution

\section{Introduction}

The discussion on the new horizons in Islamic Education actively started since the First Conference on Muslim Education held in Makkah in 1977 (Syed Ali Ashraf, 1994). Due to the high awareness of the importance of Islamic Education around the world, the conference has been extended several times to gather Islamic thinkers to discuss issues related to the Islamic Education world. The trial was subsequently continued in Islamabad (1980), Dakka (1981), Jakarta (1982), Cairo (1982) and Amman (1990) (Wan Mohd Nor, 2003). From this point on, various efforts have been made in Islamic countries to develop and implement the philosophy and concept of Islamic Education that is in line with the demands and challenges of the 21 st century.

Among the conference resolutions issued are related to the education system mulfunction within the Muslim nation. The discrepancy in the education system that is dualism and secularism is a major cause of the weakness of Muslims today (Mohd Nasir, 2005). This education system also causes Muslim students to be separated from the vision of Islam as well as the history of Islamic magnificence. To make things worse, the Western-based educational system only places more emphasis on intellectual abilities, which neglects religion and moral 
values.

In the context of Brunei Darussalam, the government heavily emphasized on education, especially in Islamic Education. Islamic Education teaching and learning starts from pre-school up to university level. In fact, it has become compulsory since 2012 for Muslim children aged seven to fifteen to be sent to a religious primary school (pelitabrunei.gov.bn). The implementation of this order is to ensure that every child is given due attention from the very beginning.

In addition, the government has also formulated a long-term policy to guide the development of the nation and achieve the nation's progress. In this regard, the Vision Brunei 2035 (2007-2035) has been set up based on three main components; (1) All citizens of the country need to be united in loyalty to the Sultan and the State, (2) the people need to be convinced of their noble values and; (3) the people should practice the tradition of social tolerance and harmony (Brunei Government, 2008). This component clearly shows that the country is concerned with the application of values and social harmony in achieving the nation's progress and development.

\section{Problem Statement}

As it is known, the Ministry of Education has placed Islamic Education as a core subject in SPN21. Apart from providing students with the understanding of religious knowledge, the need to make Islam a way of life and the cultivation of noble values is also given attention. This optimum emphasis is to ensure that the state will be able to produce a generation of proficient and quality workforce based on noble values. This matter is respected and affirmed by His Majesty in an attempt to improve the quality of education in line with the progress of the nation.

As a matter of fact, the application of value does not only focus on certain subjects. Application of value should be absorbed through the contents of all subjects (curriculum) and co-curriculum activities performed directly or indirectly in or out of the classroom (Abd Rahim, 2001; Nik Azis, 1996; Nik Zaharah, 2007; Tajul Ariffin, 1998). In the SPN21, the application of noble values is emphasized in two subjects: Islamic Religious Education and Islamic Monarchy based on national philosophy (Aliff \& Gamal, 2016; Ministry of Education, 2009).

As everyone knows, the process of applying value in schools depends on the practice of the teachers. The implementation of good and effective teaching practices can help students to improve their knowledge and appreciate religious values (Abdul Rahim, 1993; Gamal, Ahmad, Aliff \& Salwa, 2014). The previous studies show that the role of teachers and the application of value in morals subject have a positive and interdependent relationship (Ahmad Zabidi, 2006; Mohamad Khairi \& Asmawati, 2010; Nawi, Hamzah, Ren \& Tamuri, 2015; Noornajihan \& Ab. Halim, 2013; Zaharah, 2005). However, studies on the teaching practices of teachers in applying values in students have not yet reached a satisfactory level and are still questionable (Ab Halim et al., 2010; Mohd Aderi \& Rohani, 2009; Maimun Aqsha \& Roslan, 2005; Maimun Aqsha \& Sabariah, 2008; Rosiah, 2010).

In addition, the effectiveness of ICT-based teaching aids in applying values to students is doubted. Indeed, various materials have been designed and developed with the aim of improving the achievement in examinations and attracting students' interest. However, most of the material fails to function as a value-added agent in the development of values in students (Sidek, 2011; Zuraidah \& Aizan, 2014). On top of that, the uncontrollable use of ICT-based materials makes students become robotic and this erodes human nature and ignores the role of teachers as 
"qudwah" which means "good example" or "good model" in shaping the moral character and behaviour of students (Sidek, 2006).

In fact, there are various factors that contribute to social illness or the decline in values among adolescents. Among them are the negative effects of the mass media (Ab Halim \& Zarin, 2009; Ahmad Munawar \& Mohd Nor Shahizan, 2011; Wan Norina et al., 2013), parents and family problems (Ab Halim \& Zarin, 2009) and peer influence (Zainudin \& Norazmah, 2011). However, many studies have revealed that the lack of religious exposure is the most dominant factor that contribute to students' negative behaviour (Ab Halim et al., 2004; Campbell, 2010; Fauziah et al., 2012a; Fauziah et al., 2012b; French et al., 2008; Sabita \& Mahmood, 1995; Syarifah et al., 2010; Zainudin \& Norazmah, 2011).

This scenario explains that religion is the most important factor in the development of a person's morals. This formation of morality begins with the application of values so as to highlight the noble character. The lack of religious appreciation also makes human becoming more materialistic and prone to the demands of desires (Tajul Ariffin \& Nor 'Aini, 2002). The low level of religious appreciation signals the weakness in self-belief and this is feared to cause the tendency to bad behavioural conduct (Mardzelah, 2006; Hasan, 1997). This clearly shows that it is important to apply noble values among students as an attempt to live the true religion.

Therefore, this study attempts to identify the effectiveness of value through online modules. An online module will be specially designed online and equipped with multimedia material to apply value indirectly. This module will be used by treatment group students during teaching and learning sessions in Islamic Education subjects. The students in the control group, on the other hand, will go through conventional learning.

\section{Literature Review}

In this study, problem-based learning strategies or PBL is considered appropriate as students are exposed to various situations in the form of conflict or dilemma. According to Abd Rahim (1993), the use of conflict situations is aimed at helping students to realize and identify personal values and values in others. Awareness among students can be applied through dilemma conflict situations via activities such as role play, real story, movie use, acting, small group discussion, game or simulation. In addition, learning through PBL also encourages students to share personal value with the value of others and identify certain value systems or examine patterns of personal behaviour.

As a matter of fact, PBL was originally developed specifically for medical students. PBL was first used by Howard Barrows and his colleagues at the Medical School, McMaster University in Hamilton, Ontario, Canada (Neville, 2009). However, since the use of PBL contributed many benefits to learning such as stimulating student learning, generating ideas and motivating students to think, it has been expanded into various fields including in education (Barrows \& Tamblyn, 1980). Savin-Baden and Major (2004) pointed out that learning through $\mathrm{PBL}$ is evolving into various fields due to the need to produce highly qualified and high-quality professionals. Initially the PBL was used only in McMaster University, Canada in 1980 (Barrows \& Tamblyn, 1980) and it was then spread throughout the world including United States, United Kingdom, Denmark, Finland, France, Africa and Sweeden (Savin-Baden \& Major, 2004)

Generally, PBL is one of the student-centered learning methods. This learning method provides students with the problem first as a stimulant of learning. When viewed from the 
definition of Barrows and Tamblyn (1980), the PBL is a form of learning that results from the process of understanding or resolving a problem. According to them, the discovery of the problem is the first step in the learning process. This problem then encourages the use of various problem and reasoning skills as well as encouraging students to find new information. When this process occurs, the existing knowledge organization within the student can be established in order to find a solution to solve a problem.

To date, PBL has been implemented in various fields including in teaching science (Argaw et al., 2017), healthcare training (Yew \& Goh, 2016), mathematics (Paruntu et al. 2018), vocational skills (Chiang \& Lee, 2016), engineering (Wang et al., 2017), history education (Wynn, 2016), and English (Hwang, 2017). However, there has been no emperical study in Islamic education. There is a study conducted in Islamic education but it is only limited to theoretical aspects such as the study by Hasan \& Rohmatul (2018) and the study by (Aliff \& Gamal, 2016) that is too general and only based at the students' view on the application of PBL in lessons only. Therefore, this study should be carried out to focus on assessing the effectiveness of applying values through the teaching and learning of PBL in Islamic Education. The study was also conducted empirically to ensure that the findings will be able to measure positive effects, especially in behavioral changes by implementing noble values.

\section{Research Questions}

The purpose of this study is to answer the four following questions;

1) Is there a difference in the mean score of the pre-emptive level of application of all noble values between the treatment group and the treatment group?

2) Is there a difference in the mean score of the pre and post-implementation level of all the noble values of the treatment group?

3) Is there a significant difference to the mean score of the pre and post-test implementation of all the values of the control group?

4) Is there a significant difference to the post-stage test mean score of applying all the noble values between the treatment group and the control group?

\section{Hypothetical Studies}

To test the effectiveness of applying values through the online PBL among students, several research hypotheses were developed to strengthen the findings of the study. The hypothesis to be used in this study is the null hypothesis (Ho). A total of four research hypotheses were set up to test the following questions:

$\mathrm{H}_{0} 1$ There is no significant difference in the pre-test level of application of all noble values between the treatment group and the control group.

$\mathrm{H}_{0} 2$ There is no significant difference between the pre-test score and the post implementation level of all the noble values of the treatment group.

$\mathrm{H}_{0} 3$ There is no significant difference between the pre-test score and post-implementation level of all values of the control group.

$\mathrm{H}_{0} 4$ There is no significant difference in the post-stage test of the application of all noble values between the treatment group and the control group. 


\section{Research Methodology}

This study is a quasi-experimental study involving two classes in Polytechnic of Brunei Darussalam. These two classes are almost identical in terms of the background and student achievement. Treatment group were taught using PBL modules developed specifically in Islamic Education while the control group was taught using conventional modules. Both groups went through 11 weeks of teaching and learning session (a meeting of 1 hour 30 minutes each) over a semester. Researchers also ensured that the students had the same background, were taught by the same teacher, learnt the same topic, and in the same week.

This study conducts pre-test and post-test on treatment group and control group. The research instrument consists of a set of questionnaires that consists a likert scale from 1 to 5 to measure the value of noble values, a student interview form, as well as a teacher observation form. The value-applying questionnaire was initiated in early 2014 in several schools in BruneiMuara and Kuala Belait, Brunei Darussalam to enhance the reliability of the questionnaire.

Pre-test and post-test are conducted to measure the value-level variables of prior and postintervention towards the treatment and control groups. Based on the comparison results, the effect of interventions using PBL Modules can be determined whether it has been successful or otherwise. Experiment designs are summarized as in the following table.

Table 1. Experiment Design Model

\begin{tabular}{cccc}
\hline Group & Pre-test & Treatment & Post-test \\
\hline Treatment & $\mathrm{O}_{1}$ & $\mathrm{X}$ & $\mathrm{O}_{2}$ \\
Control & $\mathrm{O}_{3}$ & - & $\mathrm{O}_{4}$ \\
\hline
\end{tabular}

$\mathrm{O}_{1}$ and $\mathrm{O}_{3}=$ Pre-test

$\mathrm{O}_{2}$ and $\mathrm{O}_{4}=$ Post-test

$\mathrm{X} \quad=$ Treatment (group were taught using PBL modules developed)

$=$ Control (group were taught using conventional modules)

\section{Research Findings}

\section{1) Difference Analysis of Test Mean Score of Pre-Applying Noble Values Level between the Treatment Group and the Control Group}

The independent sample t-test was conducted to see the difference in the mean score of pre-noble values among students from the treatment group compared with students from the control group. The independent sample t-test is used to detect the differences of two independent variables. The findings of the independent t-test can be seen in the table below.

Table 2. The t-test relies on the mean score of pre-application of noble values for treatment and control groups

\begin{tabular}{|c|c|c|c|c|c|c|c|}
\hline & Noble Value & Group & $\mathbf{N}$ & Mean & SD & $\mathbf{t}$ & Sig. \\
\hline \multirow[t]{2}{*}{1.} & Gratitute & Treatment & 37 & 3.735 & 0.485 & -0.636 & 0.527 \\
\hline & & Control & 44 & 3.805 & 0.493 & & \\
\hline \multirow[t]{2}{*}{2.} & Patience & Treatment & 37 & 3.469 & 0.557 & 0.076 & 0.940 \\
\hline & & Control & 44 & 3.458 & 0.634 & & \\
\hline
\end{tabular}




\begin{tabular}{|c|c|c|c|c|c|c|c|}
\hline & Noble Value & Group & $\mathbf{N}$ & Mean & SD & $\mathbf{t}$ & Sig. \\
\hline 3. & Mind the tongue & $\begin{array}{l}\text { Treatment } \\
\text { Control }\end{array}$ & $\begin{array}{l}37 \\
44\end{array}$ & $\begin{array}{l}3.838 \\
3.920\end{array}$ & $\begin{array}{l}0.516 \\
0.482\end{array}$ & -0.737 & 0.463 \\
\hline 4. & Humble & $\begin{array}{l}\text { Treatment } \\
\text { Control }\end{array}$ & $\begin{array}{l}37 \\
44\end{array}$ & $\begin{array}{l}3.868 \\
3.975\end{array}$ & $\begin{array}{l}0.455 \\
0.457\end{array}$ & -1.056 & 0.294 \\
\hline 5. & $\begin{array}{l}\text { Spread } \\
\text { salam }\end{array}$ & $\begin{array}{l}\text { Treatment } \\
\text { Control }\end{array}$ & $\begin{array}{l}37 \\
44\end{array}$ & $\begin{array}{l}3.402 \\
3.499\end{array}$ & $\begin{array}{l}0.488 \\
0.462\end{array}$ & -0.921 & 0.360 \\
\hline 6. & Love & $\begin{array}{l}\text { Treatment } \\
\text { Control }\end{array}$ & $\begin{array}{l}37 \\
44\end{array}$ & $\begin{array}{l}3.914 \\
4.049\end{array}$ & $\begin{array}{l}0.590 \\
0.516\end{array}$ & -1.090 & 0.279 \\
\hline 7. & Justice & $\begin{array}{l}\text { Treatment } \\
\text { Control }\end{array}$ & $\begin{array}{l}37 \\
44\end{array}$ & $\begin{array}{l}3.838 \\
3.880\end{array}$ & $\begin{array}{l}0.404 \\
0.561\end{array}$ & -0.379 & 0.705 \\
\hline 8. & Trust & $\begin{array}{l}\text { Treatment } \\
\text { Control }\end{array}$ & $\begin{array}{l}37 \\
44\end{array}$ & $\begin{array}{l}3.955 \\
4.017\end{array}$ & $\begin{array}{l}0.506 \\
0.570\end{array}$ & -0.517 & 0.606 \\
\hline 9. & Shyness & $\begin{array}{l}\text { Treatment } \\
\text { Control }\end{array}$ & $\begin{array}{l}37 \\
44\end{array}$ & $\begin{array}{l}4.092 \\
4.146\end{array}$ & $\begin{array}{l}0.561 \\
0.571\end{array}$ & -0.424 & 0.673 \\
\hline 10. & Dignity & $\begin{array}{l}\text { Treatment } \\
\text { Control }\end{array}$ & $\begin{array}{l}37 \\
44\end{array}$ & $\begin{array}{l}3.838 \\
3.936\end{array}$ & $\begin{array}{l}0.823 \\
0.641\end{array}$ & -0.605 & 0.547 \\
\hline 11. & $\begin{array}{l}\text { Submission } \\
\text { Allah }\end{array}$ & $\begin{array}{l}\text { Treatment } \\
\text { Control }\end{array}$ & $\begin{array}{l}37 \\
44\end{array}$ & $\begin{array}{l}4.099 \\
4.155\end{array}$ & $\begin{array}{l}0.604 \\
0.484\end{array}$ & -0.465 & 0.643 \\
\hline 12. & Punctuality & $\begin{array}{l}\text { Treatment } \\
\text { Control }\end{array}$ & $\begin{array}{l}37 \\
44\end{array}$ & $\begin{array}{l}3.069 \\
3.075\end{array}$ & $\begin{array}{l}0.447 \\
0.610\end{array}$ & -0.054 & 0.957 \\
\hline 13. & Moderation & $\begin{array}{l}\text { Treatment } \\
\text { Control }\end{array}$ & $\begin{array}{l}37 \\
44\end{array}$ & $\begin{array}{l}4.112 \\
3.935\end{array}$ & $\begin{array}{l}0.505 \\
0.550\end{array}$ & 1.496 & 0.139 \\
\hline 14. & Avoidance of sin & $\begin{array}{l}\text { Treatment } \\
\text { Control }\end{array}$ & 37 & 3.992 & $\begin{array}{l}0.635 \\
0.603\end{array}$ & 0.156 & 0.876 \\
\hline
\end{tabular}

Significant level : $\mathrm{p}<0.05$

The independent sample t-test analysis in the above table is carried out to see the difference in the mean score of pre-noble values among students from the treatment group compared with students from the control group. The findings show that there is no significant difference between the test mean score of pre-applying noble values level between the treatment group and the treatment group.

Since all $\mathrm{p}$ values are greater than $0.05(\mathrm{p}=0.00>0.05)$, the zero Hypothesis $(\mathrm{H} 01)$ is accepted. This means that there is no significant difference between the test score of noble values level between the treatment group and the treatment group. The pre-level test value of noble values for both groups is the same. It can be explained that post-stage test scores of the 
application of noble values that will be analyzed later will not be affected by this pre test value. This means that the increased value of the post-test is due to the treatment process (the use of PBL Modules and the usual) performed on both groups later on.

\section{2) Difference Analysis of Difference in the Mean Score of the Pre And Post- Implementation Level of All the Noble Values for the Experiment Group}

To answer this research question, a hypothesis of the study has been developed. All hypotheses are expressed in the form of zero statements and have been tested using SPSS software. To test the hypothesis 1, paired sample t-test is suitable for use as it can detect the differences between two variables. To carry out this test, the researcher has ensured that the study data fulfilled the conditions specified by Pallant (2007) such as the balance between samples and normalized. Relative t-test findings can be seen in the table below.

Table 3. The t-test pairs the mean score of the pre and post-implementation of noble values for treatment groups

\begin{tabular}{|c|c|c|c|c|c|c|c|}
\hline & Noble Value & Group & $\mathbf{N}$ & Mean & SD & $\mathbf{t}$ & Sig. \\
\hline \multirow[t]{2}{*}{1.} & Gratitute & Pre & 37 & 3.735 & 0.485 & -1.565 & 0.126 \\
\hline & & Post & 37 & 3.880 & 0.541 & & \\
\hline \multirow[t]{2}{*}{2.} & Patience & Pre & 37 & 3.469 & 0.557 & -3.810 & $0.001 *$ \\
\hline & & Post & 37 & 3.740 & 0.609 & & \\
\hline \multirow[t]{2}{*}{3.} & Mind the tongue & Pre & 37 & 3.838 & 0.516 & -2.546 & $0.015 * *$ \\
\hline & & Post & 37 & 4.054 & 0.406 & & \\
\hline \multirow[t]{2}{*}{4.} & Submission to Allah & Pre & 37 & 3.868 & 0.455 & -3.273 & $0.002 * *$ \\
\hline & & Post & 37 & 4.130 & 0.409 & & \\
\hline \multirow[t]{2}{*}{5.} & Spread salam & Pre & 37 & 3.402 & 0.488 & -2.192 & $0.035 * *$ \\
\hline & & Post & 37 & 3.591 & 0.524 & & \\
\hline \multirow[t]{2}{*}{6.} & Love & Pre & 37 & 3.914 & 0.590 & -2.439 & $0.020 * *$ \\
\hline & & Post & 37 & 4.081 & 0.487 & & \\
\hline \multirow[t]{2}{*}{7.} & Justice & Pre & 37 & 3.838 & 0.404 & -2.612 & $0.013 * *$ \\
\hline & & Post & 37 & 4.054 & 0.355 & & \\
\hline \multirow[t]{2}{*}{8.} & Trust & Pre & 37 & 3.955 & 0.506 & -2.412 & $0.021 * *$ \\
\hline & & Post & 37 & 4.153 & 0.504 & & \\
\hline \multirow[t]{2}{*}{9.} & Shyness & Pre & 37 & 4.092 & 0.561 & -1.281 & 0.208 \\
\hline & & Post & 37 & 4.211 & 0.447 & & \\
\hline \multirow[t]{2}{*}{10.} & Dignity & Pre & 37 & 3.838 & 0.823 & -3.235 & $0.003 * *$ \\
\hline & & Post & 37 & 4.222 & 0.492 & & \\
\hline \multirow[t]{2}{*}{11.} & Submission to Allah & Pre & 37 & 4.099 & 0.604 & -2.171 & $0.037 * *$ \\
\hline & & Post & 37 & 4.306 & 0.514 & & \\
\hline \multirow[t]{2}{*}{12.} & Punctuality & Pre & 37 & 3.069 & 0.447 & -3.327 & $0.002 * *$ \\
\hline & & Post & 37 & 3.360 & 0.511 & & \\
\hline
\end{tabular}




\begin{tabular}{llllllll}
\hline & Noble Value & Group & N & Mean & SD & t & Sig. \\
\hline 13. & Moderation & Pre & 37 & 4.112 & 0.505 & -.734 & 0.468 \\
& & Post & 37 & 4.179 & 0.521 & & \\
14. & Avoidance of $\sin$ & Pre & 37 & 3.992 & 0.635 & -1.013 & 0.318 \\
& Post & 37 & 4.100 & 0.552 & &
\end{tabular}

Significant level: ${ }^{*} \mathrm{p}<0.01$

The table above shows a t-test analysis of treatment groups that uses PBL modules of noble values. T-test analysis showed that there was a significant difference between pre-test and posttest against 10 of 14 noble values. The result shows that there are ten values of $p$ less than 0.05 $(p=0.00<0.05)$, that is patient $(p=0.001)$, mind the tongue $(p=0.015)$, submission to Allah $(p=0.02)$, spread salam $(p=0.035)$, love $(p=0.020)$, justice $(p=0.013)$, trust $(p=0.021)$, dignity $(\mathrm{p}=0.003)$, submission to Allah $(\mathrm{p}=0.037)$ and punctuality $(\mathrm{p}=0.002)$. Due to the $\mathrm{p}$ value less than $(p=0.00<0.05)$ then the null hypothesis $(\mathrm{H} 02)$ is rejected. This means that 10 out of 14 noble values have been successfully being applied to the students after they use the iPBL Module. The rest of the noble values of gratitude, shyness, humble and avoidance of sin have also increased based on mean but not significant.

\section{3) Difference Analysis to the Mean Score of the Pre and Post-Test Implementation of All the Values of the Control Group}

To answer this research question, a hypothesis of the study has been developed. All hypotheses are expressed in the form of zero statements and have been tested using SPSS software. To test the hypothesis 1, paired sample t-test is used as it can detect the differences between two variables. To carry out this test, the researcher has ensured that the study data fulfilled the conditions specified by Pallant (2007) such as the balance between samples and normalized condition. Relative t-test findings can be seen in the table below.

Table 4. The t-test pairs the mean score of the pre and post-test implementation of the control group

\begin{tabular}{|c|c|c|c|c|c|c|c|}
\hline & Noble Values & Group & $\mathbf{N}$ & Mean & SD & $\mathbf{t}$ & Sig. \\
\hline \multirow[t]{2}{*}{1.} & Gratitute & Pre & 44 & 3.804 & 0.493 & 0.092 & 0.927 \\
\hline & & Post & 44 & 3.799 & 0.501 & & \\
\hline \multirow[t]{2}{*}{2.} & Patience & Pre & 44 & 3.458 & 0.634 & -0.983 & 0.331 \\
\hline & & Post & 44 & 3.534 & 0.473 & & \\
\hline \multirow[t]{2}{*}{3.} & Mind the tongue & Pre & 44 & 3.920 & 0.482 & 0.742 & 0.462 \\
\hline & & Post & 44 & 3.849 & 0.529 & & \\
\hline \multirow[t]{2}{*}{4.} & Submission to Allah & Pre & 44 & 3.975 & 0.457 & -0.079 & 0.937 \\
\hline & & Post & 44 & 3.982 & 0.567 & & \\
\hline \multirow[t]{2}{*}{5.} & Spread salam & Pre & 44 & 3.499 & 0.462 & -0.461 & 0.647 \\
\hline & & Post & 44 & 3.533 & 0.556 & & \\
\hline 6. & Love & Pre & 44 & 4.049 & 0.516 & 0.466 & 0.643 \\
\hline
\end{tabular}




\begin{tabular}{|c|c|c|c|c|c|c|c|}
\hline & Noble Values & Group & $\mathbf{N}$ & Mean & SD & $\mathbf{t}$ & Sig. \\
\hline & & Post & 44 & 4.011 & 0.615 & & \\
\hline \multirow[t]{2}{*}{7.} & \multirow[t]{2}{*}{ Justice } & Pre & 44 & 3.880 & 0.561 & \multirow[t]{2}{*}{0.000} & \multirow[t]{2}{*}{1.000} \\
\hline & & Post & 44 & 3.890 & 0.531 & & \\
\hline \multirow[t]{2}{*}{8.} & \multirow[t]{2}{*}{ Trust } & Pre & 44 & 4.017 & 0.570 & \multirow[t]{2}{*}{-0.398} & \multirow[t]{2}{*}{0.693} \\
\hline & & Post & 44 & 4.053 & 0.490 & & \\
\hline \multirow[t]{2}{*}{9.} & \multirow[t]{2}{*}{ Shyness } & Pre & 44 & 4.146 & 0.571 & \multirow[t]{2}{*}{0.292} & \multirow[t]{2}{*}{0.772} \\
\hline & & Post & 44 & 4.122 & 0.562 & & \\
\hline \multirow[t]{2}{*}{10.} & \multirow[t]{2}{*}{ Dignity } & Pre & 44 & 3.936 & 0.641 & \multirow[t]{2}{*}{-0.789} & \multirow[t]{2}{*}{0.435} \\
\hline & & Post & 44 & 4.155 & 0.673 & & \\
\hline \multirow[t]{2}{*}{11.} & \multirow[t]{2}{*}{ Submission to Allah } & Pre & 44 & 4.015 & 0.484 & \multirow[t]{2}{*}{-1.686} & \multirow[t]{2}{*}{0.099} \\
\hline & & Post & 44 & 4.269 & 0.492 & & \\
\hline \multirow[t]{2}{*}{12.} & \multirow[t]{2}{*}{ Punctuality } & Pre & 44 & 3.075 & 0.610 & \multirow[t]{2}{*}{-2.274} & \multirow[t]{2}{*}{$0.028 * *$} \\
\hline & & Post & 44 & 3.239 & 0.680 & & \\
\hline \multirow[t]{2}{*}{13.} & \multirow[t]{2}{*}{ Moderation } & Pre & 44 & 3.935 & 0.550 & \multirow[t]{2}{*}{-2.033} & \multirow[t]{2}{*}{$0.048 * *$} \\
\hline & & Post & 44 & 4.055 & 0.502 & & \\
\hline \multirow[t]{2}{*}{14.} & \multirow[t]{2}{*}{ Avoidance of sin } & Pre & 44 & 3.971 & 0.603 & \multirow[t]{2}{*}{-1.965} & \multirow[t]{2}{*}{0.056} \\
\hline & & Post & 44 & 4.139 & 0.641 & & \\
\hline
\end{tabular}

Significant level: $* \mathrm{p}<0.01$

$$
* * \mathrm{p}<0.05
$$

The table above shows a t-test analysis of the control group that has undergone the usual teaching and learning process. The t-test analysis showed that there was a significant difference between the pre-test and the post-test for the control group against two (2) of 14 noble values. The findings show that there are two (2) $p$ values less than $0.05(\mathrm{p}=0.00<0.05)$, which is time $(p=0.028)$ and medium $(p=0.048)$ values. Due to the $p$ value less than $(p=0.00<0.05)$ then the null hypothesis (H03) is rejected. This means that two (2) out of 14 noble values were successfully applied after they undergo the normal process of teaching and learning for the Islamic Education courses. However, there are some other noble values such as patience, humble, giving salam, trust, dignity, submission to Allah and avoidance of sin have also increased based on mean the value but not significant. While the rest of the noble values which are gratitude, mind your tongue, love and shyness experience a decrease to the mean score. Only the value of justice remains and does not change.

\section{4) Difference Analysis of Post-Stage Mean Test Score Level Between the Treatment and Control Groups}

The independent sample t-test was conducted to see the difference in the mean score of the post-stage test on the noble values towards the treatment group (E) and the control group (C). The independent t-test is suitable to be used to detect the differences of two independent variables. The findings of the independent t-test can be seen in the table below. 
Table 5. The independent sample t-test does not rely on the mean score of post-stage test of pursuit of noble values between experiment and control groups

\begin{tabular}{|c|c|c|c|c|c|c|c|}
\hline & Noble Values & Group & $\mathbf{N}$ & Mean & SD & $\mathbf{t}$ & Sig. \\
\hline \multirow[t]{2}{*}{1.} & Gratitute & Treatment & 37 & 3.880 & 0.541 & 0.697 & 0.488 \\
\hline & & Control & 44 & 3.799 & 0.501 & & \\
\hline \multirow[t]{2}{*}{2.} & Patience & Treatment & 37 & 3.740 & 0.609 & 1.707 & 0.092 \\
\hline & & Control & 44 & 3.534 & 0.474 & & \\
\hline \multirow[t]{2}{*}{3.} & Mind the tongue & Treatment & 37 & 4.279 & 1.575 & 1.705 & 0.092 \\
\hline & & Control & 44 & 3.849 & 0.529 & & \\
\hline \multirow[t]{2}{*}{4.} & Submission to Allah & Treatment & 37 & 4.130 & 0.409 & 1.323 & 0.190 \\
\hline & & Control & 44 & 3.982 & 0.567 & & \\
\hline \multirow[t]{2}{*}{5.} & Sebarkan & Treatment & 37 & 3.591 & 0.524 & 0.482 & 0.631 \\
\hline & salam & Control & 44 & 3.533 & 0.556 & & \\
\hline \multirow[t]{2}{*}{6.} & Love & Treatment & 37 & 4.081 & 0.487 & 0.558 & 0.578 \\
\hline & & Control & 44 & 4.011 & 0.615 & & \\
\hline \multirow[t]{2}{*}{7.} & Justice & Treatment & 37 & 4.054 & 0.355 & 1.700 & 0.093 \\
\hline & & Control & 44 & 3.880 & 0.531 & & \\
\hline \multirow[t]{2}{*}{8.} & Trust & Treatment & 37 & 4.153 & 0.504 & 0.905 & 0.368 \\
\hline & & Control & 44 & 4.053 & 0.490 & & \\
\hline \multirow[t]{2}{*}{9.} & Shyness & Treatment & 37 & 4.211 & 0.447 & 0.769 & 0.444 \\
\hline & & Control & 44 & 4.123 & 0.563 & & \\
\hline \multirow[t]{2}{*}{10.} & Dignity & Treatment & 37 & 4.222 & 0.492 & 1.553 & 0.124 \\
\hline & & Control & 44 & 4.015 & 0.673 & & \\
\hline \multirow[t]{2}{*}{11.} & Submission to Allah & Treatment & 37 & 4.306 & 0.514 & 0.334 & 0.740 \\
\hline & & Control & 44 & 4.269 & 0.492 & & \\
\hline \multirow[t]{2}{*}{12.} & Punctuality & Treatment & 37 & 3.360 & 0.511 & 0.896 & 0.373 \\
\hline & & Control & 44 & 3.239 & 0.680 & & \\
\hline \multirow[t]{2}{*}{13.} & Moderation & Treatment & 37 & 4.179 & 0.521 & 1.088 & 0.280 \\
\hline & & Control & 44 & 4.055 & 0.502 & & \\
\hline \multirow[t]{2}{*}{14.} & Avoidance of $\sin$ & Treatment & 37 & 4.100 & 0.552 & -0.284 & 0.777 \\
\hline & & Control & 44 & 4.139 & 0.641 & & \\
\hline
\end{tabular}

Significant level: $\mathrm{p}<0.05$

The independent sample t-test analysis in the above table is carried out to see the difference in the mean score of the post-stage test on the noble values towards the treatment group (E) and the control group (C). The t-test analysis showed that there was no significant difference between the post-stage test scores of the application of noble values between the treatment group and the control group. Since all values of pare greater than $0.05(p>0.05)$, the zero Hypothesis 
(H04) is accepted. This means that there is no significant difference in the post-stage test score of applying noble values between the treatment group and the control group. This shows that the level of applying value for both groups increases together. This increase has no difference whether to undergo teaching and learning using the PBL Module or through the usual teaching and learning process.

As the findings did not prove any difference in the teaching method used in both groups, the researchers tried to identify the mean score increase using the gained score mean analysis. This mean increase analysis is usually used to identify the true increase in the mean levels between pre and post tests within the group (Becker, 2000; Jamil, 2012). According to them, a mean increase score can be obtained when the pre-test score is rejected by the post test scores. The result of this rejection is named as a gained score mean before and after learning.

However, this mean increase analysis has a weakness and can not be used if the pre-test score is too high. This will lead to a slight increase in scores when compared with post-test scores. Therefore, the researcher has to make sure that the pre-test score for both groups are the same, therefore, this mean increase analysis can be used. Furthermore, both groups are homogeneous. The independent t-test findings (an analysis of the increase in post-test and pretest mean score) can be seen in the table below.

Table 6. Independent sample t-test analysis of the mean score increase (post-test and pretest) towards the application of noble values between the treatment and control groups

\begin{tabular}{|c|c|c|c|c|c|c|c|}
\hline & Noble Values & Group & $\mathbf{N}$ & Mean Increase & SD & $\mathbf{t}$ & Sig. \\
\hline \multirow[t]{2}{*}{1.} & Gratitute & Treatment & 37 & 0.145 & 0.562 & 1.387 & 0.169 \\
\hline & & Control & 44 & -0.006 & 0.412 & & \\
\hline \multirow[t]{2}{*}{2.} & Patience & Treatment & 37 & 0.271 & 0.433 & 1.836 & 0.070 \\
\hline & & Control & 44 & 0.076 & 0.511 & & \\
\hline \multirow[t]{2}{*}{3.} & Mind the tongue & Treatment & 37 & 0.441 & 1.483 & 2.079 & $0.041 * *$ \\
\hline & & Control & 44 & -0.071 & 0.636 & & \\
\hline \multirow[t]{2}{*}{4.} & Submission to Allah & Treatment & 37 & 0.262 & 0.487 & 2.142 & $0.035 * *$ \\
\hline & & Control & 44 & 0.007 & 0.571 & & \\
\hline \multirow[t]{2}{*}{5.} & Spread & Treatment & 37 & 0.189 & 0.525 & 1.389 & 0.169 \\
\hline & salam & Control & 44 & 0.034 & 0.482 & & \\
\hline \multirow[t]{2}{*}{6.} & Love & Treatment & 37 & 0.167 & 0.416 & 1.902 & 0.061 \\
\hline & & Control & 44 & -0.037 & 0.528 & & \\
\hline \multirow[t]{2}{*}{7.} & Justice & Treatment & 37 & 0.216 & 0.504 & 1.876 & 0.064 \\
\hline & & Control & 44 & 0.000 & 0.527 & & \\
\hline \multirow[t]{2}{*}{8.} & Trust & Treatment & 37 & 0.198 & 0.500 & 1.318 & 0.191 \\
\hline & & Control & 44 & 0.036 & 0.594 & & \\
\hline \multirow[t]{2}{*}{9.} & Shyness & Treatment & 37 & 0.119 & 0.565 & 1.179 & 0.242 \\
\hline & & Control & 44 & -0.023 & 0.516 & & \\
\hline \multirow[t]{2}{*}{10.} & Dignity & Treatment & 37 & 0.384 & 0.722 & 1.989 & $0.050 * *$ \\
\hline & & Control & 44 & 0.078 & 0.659 & & \\
\hline
\end{tabular}




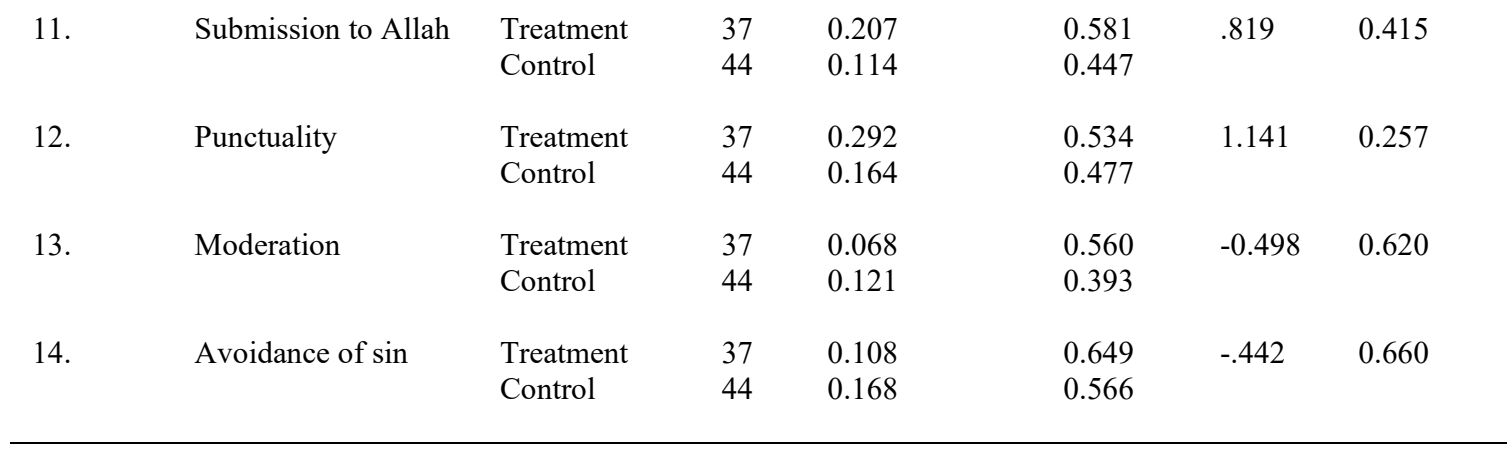

Significant level : ** $\mathrm{p}<0.05$

The table above shows an analysis of the t-test of post-stage test mean increase the application of noble values for treatment and control groups. T-test analysis showed that there was a significant difference between the pre-test and the post-test for the control group against three (3) of 14 noble values. The findings show that there are three (3) p values less than 0.05 $(\mathrm{p}=0.00<0.05)$, which is mind the tongue $(\mathrm{p}=0.041)$, submission to Allah $(\mathrm{p}=0.035)$ and guarding the dignity $(p=0.050)$. Due to the $p$ value less than $(p=0.00<0.05)$ then the null hypothesis is rejected. This means that the use of PBL modules has effectively applied three (3) noble values among the treatment groups higher than those of the control group through regular teaching and learning.

If looked into detail, the mean score of all noble values for the treatment group increased but not significant (mean $=0.068$ to 0.292 ). However, not all noble values for the control group have an increased mean score. In fact, the mean score decrease is based on a negative score on mean analysis. The noble values of mean decrease are the value of gratitude (mean = -0006), mind the tongue $(-0.071)$, love $(-0.037)$ and shyness (mean $=-0.023)$. This suggests that the usual method of teaching and learning can have a negative impact on the application of noble values compared to the use of PBL modules.

In conclusion, based on the statistical analysis of dependent t-test inference and independent sample t-test on the table 7 below, it can be concluded that three of the study questions ie iii (b), iii (c), and iii (d) have significant mean. There is only one question, however, that iii (a) does not show significant differences. However, the question of this study should provide insufficient answer as it can prove that the mean value of the pre-test level of application of the values of the two groups is the same. On the other hand, if the question of this study provides a significant answer, then the two groups cannot be compared because they differ in the pre-test score. It can be explained that the increased value in post-test is due to the treatment process (the use of PBL modules and the usual) performed on both groups (treatment and control groups). The overall score score of the application of noble values obtained through the analysis of pre-test data and post-test and comparison between the two groups is set out in the table below.

Table 7. The overall findings of inferential analysis

\begin{tabular}{llll}
\hline No. & Research Question & Test Method & Result \\
\hline
\end{tabular}




\begin{tabular}{|c|c|c|c|}
\hline iii(a) & $\begin{array}{l}\text { Is there a difference in the mean score of } \\
\text { the pre-emptive level of application of } \\
\text { all noble values between the treatment } \\
\text { group and the treatment group? }\end{array}$ & $\begin{array}{l}\text { (Independant sample t- } \\
\text { Test) }\end{array}$ & $\begin{array}{l}(\mathrm{p}=0.00>0.05) \\
\text { Not significant }\end{array}$ \\
\hline iii(b) & $\begin{array}{l}\text { Is there a difference in the mean score of } \\
\text { the pre and post-implementation level of } \\
\text { all the noble values of the treatment } \\
\text { group? }\end{array}$ & (Paired sample t-Test) & $\begin{array}{l}(p=0.00<0.05) \\
\text { Significant }\end{array}$ \\
\hline iii(c) & $\begin{array}{l}\text { Is there a significant difference to the } \\
\text { mean score of the pre and post-test } \\
\text { implementation of all the values of the } \\
\text { control group? }\end{array}$ & (Paired sample t-Test) & $\begin{array}{l}(p=0.00<0.05) \\
\text { Significant }\end{array}$ \\
\hline iii(d) & $\begin{array}{l}\text { Is there a significant difference to the } \\
\text { post-stage test mean score of applying all } \\
\text { the noble values between the treatment } \\
\text { group and the control group? }\end{array}$ & $\begin{array}{l}\text { (Independant sample t- } \\
\text { Test) }\end{array}$ & $\begin{array}{l}(p=0.00<0.05) \\
\text { Significant }\end{array}$ \\
\hline
\end{tabular}

\section{DISCUSSION}

Before discussing the question of how far the PBL Module affects the level of applying value among students, the researcher wants to explain some basic concepts that needs to be understood about values. If looking into views by Amla (2008), Asmawati (2009), Khairul Hamimah et al. (2012), Mohd Nasir (2013), about the value of the human being, a majority agrees to state that the value is abstract and implied in humanity which can not be seen with the naked eye. However, the real value can be measured by human behaviour through the actions and conversations of a person. Any action that is manifested by good or bad deed depends on the human internal system. This system is a determinant that can control one's behaviour towards good deeds or vice versa. In Islam, this has been narrated in Sahih al- Bukhari and Muslim (Ibn Hibban, 1993);

$$
\text { إن في الجسد مضغة فيد إذا صلحت كله ألا وهي الجسد كله }
$$

"Beware! There is a piece of flesh in the body if it becomes good (reformed) the whole body becomes good but if it gets spoilt the whole body gets spoilt and that is the heart..."

Therefore, this study has a variety of constraints in measuring student applying values in both the treatment group and the control group. However, researchers have tried to adopt some of the internal and external threats in the study. According to Campbell and Stanley (1963), there are several major threats to internal validity. They are history, maturity, pre-test, instrument, participant selection, mortality and participant selection interaction with maturity. While the threat to external validity involves the effects of treatment selection interactions, the effects of specific variables, reactive effects such as Hawthorne or Novelty effects, the effects of researchers and the effects of treatment pollution. These listed threats are controlled and maintained so as not to affect the treatment methods carried out.

Therefore, these findings are based on the instruments taken during the pre and post-test periods. At the same time, researchers were involved indirectly throughout the implementation process using the module to ensure that the effects resulting from the post test results were due 
to the treatment provided. In order to identify the effectiveness of using the PBL module in applying the values of the treatment and control group students, the researchers used a dependent t-test analysis to detect the differences between the two variables within the groups and in separate analyzes. The t-test analysis showed that there was a significant difference between the pre-test and the post-test against 10 of 14 noble values. The findings show that there are ten $p$ values less than $0.05(p=0.00<0.05)$. This means that the use of the PBL module has been successfully implemented almost all of the measured values.

While the value applying among the control group students also receives a significant difference score between the pre-test and the post-test. This suggests that learning through the usual methods is also effective in applying noble values to students. However, only two values were successfully applied from 10 values of noble value which are punctuality $(p=0.028)$ and humble $(\mathrm{p}=0.028)$. It can be concluded that the application of PBL modules in the experiment group are able to increase the level of applying noble values in the students compared to the control group that was taught using conventional modules. However, independent t-tests need to be carried out to identify the actual comparison of the mean value of post-test mean score of the application of values between treatment groups and control groups.

After the analysis is carried out, the result of the independent t-test which is the score of the post-test between the treatment group and the control group showed that all the $p$ values were greater than $0.05(\mathrm{p}>0.05)$. This shows that the level of value applying for both groups is equal and does not have any difference. This score explains that both groups have the same level of applying value and do not have a different level of value applying whether to undergo teaching and learning using the PBL module or through the usual teaching and learning process.

Therefore, if the researchers only conclude based on the findings of this t-test analysis alone, the researchers have failed to prove that the use of the PBL module is more effective than the use of the usual method of applying values among students. In other words, the process of applying the value either through the use of the PBL module or through the use of the normal method does not have a significant difference. The findings of this study are similar to the study by Nik Zaharah (2007) where the two groups in her study are treatment groups and control groups that are not statistically different in the pursuit of noble values. However, her statistical data shows that there is a significant difference in students' understanding. Similarly, the study by Shamsuri (2012), the effectiveness of modules in changing the affects of business idea generation can not be statistically validated. However, he only succeeded in proving that the module was effective in increasing the number and quality of ideas in business between treatment and control groups.

Alternatively, researchers are also conducting a mean increase analysis to identify which group has the highest mean increase in the value-stage implementation process. This is based on the suggestion by Jamil (2012) where this mean increase analysis is usually used to identify the actual level of increase between the pre and post test within the group. According to him, the mean increase score can be obtained when the pre-test score rejects the post-test score (postpre). The result of this rejection is named as a mean increase score before and after learning and is compared with independent $t$-test statistics.

After the analysis, the findings show that there are three (3) p values less than 0.05 which is mind the tongue $(\mathrm{p}=0.041)$, submission to Allah $(\mathrm{p}=0.035)$ and guarding the dignity $(\mathrm{p}=$ 0.050). This means that the use of the PBL module has proven to effectively apply three (3) noble values among the treatment group compared to the control group through regular teaching and learning. If looked in detail, all the values in the experiment group are increasing based on the actual mean values, but they are not significant.

For the control group, the increase in the analysis of the mean score does not only indicate 
an increase in the mean values of non-significant values, but it also shows that there is a decrease in the mean score based on a negative score towards the increase of mean analysis. Noble values that experience decrease are gratitude (mean $=-0.006)$, mind the tongue $(-0.071)$, love $(-0.037)$ and shyness (mean $=-0.023$ ). This shows that the method of teaching and learning can have a negative effect on the application of noble values compared to the teaching and learning using the PBL module.

\section{Conclusion \& Recommendation}

The application of noble values through the PBL module is a form of initiative in enhancing the understanding of students in Islamic Education courses. Apart from enhancing the understanding of the students, the PBL module also emphasizes on the application of value and this is actually the main focus of this study. Universal values are the values that are in focus. Given that there are various effective learning strategies and strategies to improve the quality of teaching and learning, this module has revealed that the adoption of PBL strategies has been effective for use in learning especially on the subjects of morality. Therefore, this module is one of the alternatives for teachers to educate students and as guideline when they are facing various problems in life.

This module is also developed online to facilitate the use of lecturers and students regardless inside or outside of the classroom. The effect of using this module also increases the level of applying values among students. The continuous use of this module is expected to further optimize the value of applying values to ensure that students do not only understanding the knowledge but are able to appreciate what they learn until they can translate them into behaviour and actions.

This study is conducted only to gauge the effectiveness of the module in applying Islamic values among students. It is recommended to take into account the effect of the module on student's moral considerations in future studies. The researcher proposes to see the impact on moral judgment as this is important in determining the student's thinking pattern in making judgments and decisions on something that happens in their life

In addition, although the research instrument used in this study is sufficient to assess the level of applying noble values among students, it is still dissatisfying. The items developed should have high reliability and legitimacy in order to achieve a high standard measuring instrument. As it is known, the value is an abstract and can not be seen, so additional instruments can be used to reinforce the findings of the study. Among other examples of instruments that can assist in future research is by adding peer-based assessment questionnaires and behavioral specific observation forms that can be applied inside or outside the teaching and learning process.

\section{Acknowledgement}

We would like to express our sincere gratitude and special thanks to everyone who has supported and made this paper possible. We would like to extend our acknowledgment of gratitude toward the significant contributors. Special thanks to Graduate Research Scholarships (GRS) sponsored by Universiti Brunei Darussalam for supporting the research. We also would like to thank Politeknik Brunei Darussalam especially Pg Dr Norkhairiah Pg Hashim for most support and encouragement. Finally, we sincerely thank to our parents, family, and friends, who 
provide the advice and support. The product of this paper would not be possible without all of their support and encouragement

\section{References}

[1] Ab. Halim Tamuri \& Zarin Ismail. (2009). Hubungan Antara Pegangan Nilai Moral dengan Media Massa: Tinjauan ke atas Remaja Melayu Luar Bandar. Jurnal SARI, 27(09): 199-212.

[2] Ab. Halim Tamuri, Adnan Yusopp, Kamisah Osman, Shahrin Awaluddin Zamri Abdul Rahim and Khadijah Abdul Razak. (2004). Keberkesanan Kaedah Pengajaran dan Pembelajaran Pendidikan Islam ke atas Pembangunan Diri Murid. Final Report of Research Project, Universiti Kebangsaan Malaysia.

[3] Ab. Halim Tamuri, Khadijah Abdul Razak \& Shahrin Awaluddin. (2010). Kaedah pengajaran pendidikan Islam: Konvensional dan inovasi. Dlm, Ab. Halim Tamuri and Nik Mohd Rahimi Nik Yusoff (penyt.). Kaedah Pengajaran dan Pembelajaran Pendidikan Islam. Bangi: Universiti Kebangsaan Malaysia Press, hal: 38-70.

[4] Abd. Rahim Abd Rashid. (1993). Pendidikan nilai merentasi kurikulum. Kuala Lumpur: Dewan Bahasa \& Pustaka.

[5] Abd. Rahim Abd. Rashid. (2001). Nilai-nilai Murni dalam pendidikan. Kuala Lumpur: Utusan Publication \& Distributors Sdn Bhd.

[6] Ahmad Munawar Ismail \& Mohd Nor Shahizan Ali. (2011). Media Penyiaran: Implikasinya dalam Pembentukan Akhlak Penuntut-penuntut Melayu di Sekolah Menengah Kebangsaan di Malaysia. Akademika, 81(3): 3-8.

[7] Ahmad Zabidi Abdul Razak. (2006). Ciri Iklim Sekolah Berkesan: Implikasinya Terhadap Motivasi Pembelajaran. Jurnal Pendidikan, 31: 3-19.

[8] Aliff Nawi \& Gamal Abdul Nasir Zakaria. (2016). Pembangunan \& Penilaian Portal iPBL dalam Kursus Pendidikan Islam di Politeknik Brunei. Jurnal Komunikasi, Malaysian Journal of Communication, 32(1), 261-285

[9] Argaw, A. S. Haile, B. B. Ayalew, B. T. \& Kuma, S. G. (2017). The Effect of Problem Based Learning (PBL) Instruction on Students' Motivation and Problem Solving Skills of Physics. Eurasia Journal of Mathematics Science and Technology Education, 13(3): 857-871

[10] Barrows, H.S. \& Tamblyn, R.M. (1980). Problem-Based Learning - An Approach to Medical Education. New York: Springer

[11] Becker, L. A. (2000). Analysis of Pretest and Posttest Scores with Gain Scores and Repeated Measures. http://www.uccs.edu/lbecker/gainscore.html\#III. Repeated Measures

[12] Brunei Government. (2008). Brunei Darussalam Long-Term Development Plan. Brunei Darussalam: Department of Economic Planning and Development, Prime Minister's Office.

[13] Campbell, D. T. \& Stanley, J. C. (1963). Experimental and quasi-experimental designs for research. Chicago: Rand McNally \& Co.

[14] Campbell, Karen, P. (2010). Transformative Learning and Spirituality: A Heuristic Inquiry into the Experience of Spiritual Learning. Tesis Doktor Falsafah, Capella University.

[15] Chiang, C. L., \& Lee, H. (2016). The effect of project-based learning on learning motivation and problem-solving ability of vocational high school students. International Journal of Information and Education Technology, 6(9), 709-712. https://doi.org/10.7763/IJIET.2016.V6.77

[16] Fauziah Ahmad, Chang Peng Kee, Normah Mustaffa, \& Wan Amizah Wan Mahmud. (2012a). Pembudayaan Dan Pemediaan Remaja: Isu Seksualiti dalam Arus Globalisasi. Laporan Penyelidikan Pusat Pengajian Media dan Komunikasi, Fakulti Sains Sosial dan Kemanusiaan, Universiti Kebangsaan Malaysia.

[17] Fauziah Ibrahim, Norulhuda Sarnon, Khadijah Alavi, Mohd Suhaimi Mohamad, Noremy Md Akhir \& Salina Nen. (2012b). Memperkasakan Pengetahuan Agama Dalam Kalangan Remaja Bermasalah Tingkah Laku: Ke Arah Pembentukan Akhlak Remaja Sejahtera. Journal of Social Sciences and Humanities, 7(1): 84-93.

[18] French, Doran, C., Eisenberg Nancy, Vaughan Julie, Purwono Urip \& Suryanti, Telie A. (2008). Religious involvement and the social competence and adjustment of indonesian muslim adolescents. 
Departmental Psychology, 44(2): 597-611.

[19] Gamal Abdul Nasir Zakaria, Ahmad Labeeb Tajudeen, Aliff Nawi \& Salwa Mahalle. (2014). ReEngineering Values into the Youth Education System: A Needs Analysis Study in Brunei Darussalam. International Education Studies, 7(5): 15-24. Retrieved from https://files.eric.ed.gov/fulltext/EJ1069306.pdf

[20] Hasan Baharun \& Rohmatul Ummah. (2018). Strengthening Students' Character in Akhlaq Subject through Problem Based Learning Model. Tadris: Jurnal Keguruan dan Ilmu Tarbiyah 3 (1): 21-30

[21] Hasan Langgulung. (1997). Asas-Asas Pendidikan Islam. Kuala Lumpur: Dewan Bahasa \& Pustaka.

[22] http://www.pelitabrunei.gov.bn/nasional/item/220-perintah-pendidikan-ugama-wajib $\left[\begin{array}{ll}6 & \text { Disember }\end{array}\right.$ 2013]

[23] Hwang, G. J., Hsu, T. C., Lai, C. L., \& Hsueh, C. J. (2017). Interaction of problem-based gaming and learning anxiety in EFL students' English listening performance and progressive behavioral patterns. Computers \& Education, 106, 26-42. doi: 10.1016/j.compedu.2016.11.010

[24] Ibnu Hibban, Muhammad bin Hibban. (1993). Sahih Ibnu Hibban bi Tartib Ibnu Balban. Muassasah Al-Risalah: Beirut.

[25] Maimun Aqsha Lubis \& Roslan Aspar. (2005). Kaedah Pengajaran Pengetahuan Agama Islam di Brunei Darussalam. Jurnal Pendidikan. 30(5): 141-150

[26] Maimun Aqsha Lubis \& Sabariah Sulaiman. (2008). Pendidikan Islam Bersepadu di Brunei Darussalam. Prosiding Wacana Pendidikan Islam Peringkat Kebangsaan Siri ke-6.UKM Bangi, Malaysia, hlm: 393-402.

[27] Mardzelah Ahmad. (2006). Sains Pemikiran dan Etika. Kuala Lumpur: PTS Professional Publishing Sdn Bhd.

[28] Mohamad Khairi Othman \& Asmawati Suhid. (2010). Peranan Sekolah dan Guru dalam Pembangunan Nilai Pelajar Melalui Penerapan Nilai Murni: Satu Sorotan. Journal of General Studies, 11: 117-130

[29] Mohd Aderi Che Noh \& Rohani Ahmad Tarmizi. (2009). Persepsi pelajar terhadap amalan pengajaran tilawah al-Quran. Jurnal Pendidikan Malaysia, 34(1): 93-109.

[30] Mohd Aliff Mohd Nawi \& Yusraini Ramlan. (2014). A Study on the Strategies and Practice of Teaching Among Trainee Teachers During Teaching Training. The Online Journal of Islamic Education, 2(1): 16 http://ojie.um.edu.my/filebank/published article/6052/Article 1 V2 I1 Jan2014.pdf

[31] Mohd Aliff Mohd Nawi, Ezad Azraai Jamsari, Adibah Sulaiman \& Mohd Isa Hamzah. (2013). Development and evaluation of ning social network for teaching training online surveillance. Turkish $\begin{array}{llll}\text { Online Journal of Distance } & \text { 245-255. }\end{array}$ http://tojde.anadolu.edu.tr/tojde50/pdf/article_21.pdf

[32] Mohd Aliff Mohd Nawi, Ezad Azraai Jamsari, Mohd Isa Hamzah, Adibah Sulaiman \& Azizi Umar. (2012). The Impact of Globalization on Current Islamic Education. Australian Journal of Basic and Applied Sciences, 6(8): 74-78 http://www.ajbasweb.com/ajbas/2012/August/74-78.pdf

[33] Mohd Nasir Omar. (2005). Gagasan Islamisasi Ilmu. Kuala Lumpur: Utusan Publication \& Distributors Sdn Bhd.

[34] Nawi, A., Hamzah, M. I., Ren, C. C., \& Tamuri, A. H. (2015). Adoption of Mobile Technology For Teaching Preparation In Improving Teaching Quality Of Teachers. International Journal of Instruction, $8(2), 113-124$

[35] Nawi, A., Hamzah, M.I. \& Abdul Rahim, A. A. (2015). Teachers Acceptance of Mobile Learning for Teaching and Learning in Islamic Education: A Preliminary Study. The Turkish Online Journal of Distance Education. 16(1): 184-192. http://tojde.anadolu.edu.tr/yonetim/icerik/makaleler/1043published.pdf

[36] Nawi, A., Zakaria, G.A.N., \& Hashim, N. (2017). Tahap Kefahaman Pelajar Terhadap Penggunaan Modul PBL dalam Pendidikan Islam di Politeknik Brunei Darussalam. Sains Humanika, 9(4): 1-7. https://sainshumanika.utm.my/index.php/sainshumanika/article/viewFile/718/736

[37] Neville, A. J. (2009). Problem-Based Learning and Medical Education Forty Years on. Medical Principles and Practice, 18(1): 1-9.

[38] Nik Azis Nik Pa. (1996). Kesepaduan dalam pendidikan matematik. Kuala Lumpur: Kementerian Pendidikan Malaysia. 
[39] Nik Zaharah Nik Yaacob. (2007). Kajian Penerapan Nilai Murni Menerusi Pengajaran Bermodul. Tesis Doktor Falsafah, Fakulti Pendidikan, Universiti Kebangsaan Malaysia.

[40] Noornajihan Jaafar \& Ab. Halim Tamuri. (2013). Hubungan antara Efikasi Kendiri dengan Kualiti Guru Pendidikan Islam Sekolah Menengah Kebangsaan Malaysia. Journal of Islamic and Arabic Education, 5(1): 41-63.

[41] Pallant, J. 2007. SPSS Survival Manual. Australia: Ligare Book Printer Sydney.

[42] Paruntu, P., Sukestiyarno, Y., \& Budi Prasetyo, A. (2018). Analysis of Mathematical Communication Ability and Curiosity Through Project Based Learning Models With Scaffolding. Unnes Journal of Mathematics Education Research, 7(1), 26-34. Retrieved from https://journal.unnes.ac.id/sju/index.php/ujmer/article/view/21864

[43] Rosiah Haji Gharif, Hajah. (2010). Penerapan Nilai-Nilai Moral Islam dalam pengajaran dan pembelajaran di sekolah-sekolah menengah. Disertasi Sarjana Pendidikan (Pengajian Islam), Institut Pendidikan Sultan Hassanal Bolkiah, Universiti Brunei Darussalam.

[44] Sabitha Marican \& Mahmood Nazar Mohamed. (1995). Pencemaran Budaya Remaja: Siapakah Yang Bertanggungjawab. Jurnal Kebajikan Masyarakat, 18(1), 21-35.

[45] Savin-Baden, M., \& Major, H. C. (2004). Foundations of problem-based learning. Birkshire, England: The Society for Research into Higher Education \& Open University Press.

[46] Sidek Baba. (2006). Pendidikan Rabbani Mengenal Allah melalui ilmu dunia. Shah Alam: Karya Bestari Sdn Bhd.

[47] Sidek Baba. (2011). Tajdid ilmu dan pendidikan. Kuala Lumpur: Yayasan Ilmuan.

[48] Syarifah, M. N., Turiman, S., Syamsilah, R., Rahil, M., Haslinda, A., Ismi Arif, I. \& Mursyid, A. (2010). Laporan Kajian Fenomena Merempit dan Potensi Remaja Lasak di FELDA. Kementerian Pengajian Tinggi Malaysia.

[49] Syed Ali Ashraf. (1994). Faith-Based Education: A Theoretical Shift from the Secular to the Transcendent. Muslim Education Quarterly 11(2):1-4.

[50] Tajul Ariffin Noordin \& Nor 'Aini Dan. (2002). Pendidikan dan Pembangunan Manusia Pendekatan Bersepadu. Bandar Baru Bangi: As-Syabab Media.

[51] Tajul Ariffin Noordin. (1993). Perspektif falsafah dan pendidikan di Malaysia. Kuala Lumpur: Dewan Bahasa dan Pustaka.

[52] Tajul Ariffin Noordin. (1998). Konsep Asas Pendidikan Sepadu. Kuala Lumpur: Nurin Enterprise.

[53] Wan Mohd Nor Wan Daud. (2003). Filsafat dan Praktik Pendidikan Islam Syed M. Naquib Al-Attas. Bandung: Pustaka Mizan.

[54] Wan Norina Wan Hamat, Zaharah Hussin, Ahmad Fkrudin Mohamed Yusoff, Ahmad Arifin Sapar. (2013). Pengaruh Media Massa Terhadap Penampilan Akhlak Pelajar Islam Politeknik Malaysia. The Online Journal of Islamic Education, 1(1): 17-27.

[55] Wang. Sunyu, A. Kolmos, A. Guerra, \& Qiao. Weifeng (Eds.), 7th International Research Symposium on PBL: Innovation, PBL and Competences in Engineering Education (pp. 75-84). Aalborg: Aalborg Universitetsforlag.

[56] Wynn, C. T., Mosholder, R. S., \& Larsen, C. A. (2016). Promoting postformal thinking in a U.S. history survey course: A problem-based approach. Journal of College Teaching and Learning, 13(1), 1-20.

[57] Yew, E. H. J., \& Goh, K. (2016). Problem-Based Learning: An Overview of its Process and Impact on Learning. Health Professions Education, 2(2), 75-79. doi:10.1016/j.hpe.2016.01.004

[58] Zaharah Hussin. (2005). Mendidik Generasi Berakhlak Mulia: Fokus Peranan Guru Pendidikan Islam. Masalah Pendidikan, 28: 79-94.

[59] Zainudin Sharif \& Norazmah Mohamad Roslan. (2011). Faktor-Faktor Yang Mempengaruhi Remaja Terlibat Dalam Masalah Sosial Di Sekolah Tunas Bakti, Sungai Lereh, Melaka. Journal of Education Psychology \& Counseling, 1 (11): 115-140

[60] Zainudin Sharif \& Norazmah Mohamad Roslan. (2011). Faktor-Faktor Yang Mempengaruhi Remaja Terlibat Dalam Masalah Sosial Di Sekolah Tunas Bakti, Sungai Lereh, Melaka. Journal of Education Psychology \& Counseling, 1 (11): 115-140

[61] Zuraidah Othman \& Aizan Ali@ Mat Zin. (2014). Pendidikan Integratif Dalam Islam: Kesepaduan Iman, Ilmu dan Amal. Journal of Al-Muqaddimah, 2 (2): 21-45. 